\title{
Particulate matter air pollution exposure: role in the development and exacerbation of chronic obstructive pulmonary disease
}

This article was published in the following Dove Press journal:

International Journal of COPD

9 June 2009

Number of times this article has been viewed

\author{
Sean H Ling \\ Stephan F van Eeden \\ James Hogg iCAPTURE Centre \\ for Pulmonary and Cardiovascular \\ Research and Heart and Lung \\ Institute, University of British \\ Columbia, Vancouver, British \\ Columbia, Canada
}

Correspondence: Stephan F. van Eeden iCapture Centre, University of British Columbia, St. Paul's Hospital, I08I

Burrard Street, Vancouver, BC,V6Z IY6

Canada

Tel + I 6048068346

Fax + I 604806835 I

Email svaneeden@mrl.ubc.ca

\begin{abstract}
Due to the rapid urbanization of the world population, a better understanding of the detrimental effects of exposure to urban air pollution on chronic lung disease is necessary. Strong epidemiological evidence suggests that exposure to particulate matter (PM) air pollution causes exacerbations of pre-existing lung conditions, such as, chronic obstructive pulmonary disease (COPD) resulting in increased morbidity and mortality. However, little is known whether a chronic, low-grade exposure to ambient PM can cause the development and progression of COPD. The deposition of PM in the respiratory tract depends predominantly on the size of the particles, with larger particles deposited in the upper and larger airways and smaller particles penetrating deep into the alveolar spaces. Ineffective clearance of this PM from the airways could cause particle retention in lung tissues, resulting in a chronic, low-grade inflammatory response that may be pathogenetically important in both the exacerbation, as well as, the progression of lung disease. This review focuses on the adverse effects of exposure to ambient PM air pollution on the exacerbation, progression, and development of COPD.
\end{abstract}

Keywords: chronic obstructive pulmonary disease, particulate matter, air pollution, alveolar macrophage

\section{Introduction}

The first, and arguably, most reported event that associated mortality with exposure to air pollution occurred from December 5th to the 9th 1952, in London, England. During the "London Fog", over 4000 more deaths than normal occurred during that period, predominantly due to heart and lung conditions. This episode in London, along with many others, brought attention to the impact of air pollution on human health ${ }^{1}$ and focused the scientific community on studying the adverse health effects of ambient air pollution. Even before recorded human history 5,300 years ago, the Tyrolean Iceman, who was discovered in September of 1991, had dust and carbon retained in his lung tissue. ${ }^{2}$ For centuries, human beings have been dealing with suspended particulate matter (PM) from dirt and burning of biomass for the purposes of cooking and warmth. ${ }^{3}$ In present day, the human respiratory tract has to deal with a much wider variety of ambient particles and gasses, predominantly from cigarette smoke, vehicle exhaust, and industrial sources.

Subjects with chronic lung conditions are particularly susceptible to the adverse effects of ambient PM. ${ }^{3}$ One such condition of particular importance, chronic obstructive pulmonary disease (COPD), is a progressive inflammatory condition of the airways, pulmonary vessels, and lung parenchyma. ${ }^{4,5} \mathrm{COPD}$ is a worldwide public health problem with significant morbidity and mortality and has been projected to be the 3rd leading cause of total mortality and the 5th leading cause of disability 
by $2020.6,7$ Because COPD is the most prevalent chronic lung condition; this population is particularly susceptible to the adverse health effects of ambient pollutants. In this review, we will focus on the effects of air pollution on the exacerbation, progression, and development of COPD.

\section{COPD:An important public health problem}

Worldwide, COPD is among one of the fastest growing chronic diseases in both the developed and the developing world. ${ }^{8}$ The clinical hallmark of COPD is progressive airflow limitation that is not reversible. ${ }^{9}$ In population-based studies, COPD affects $5 \%$ to $19 \%$ of the adult population above 40 years of age. ${ }^{10}$ Its prevalence has risen by $41 \%$ since 1982 , and its ageadjusted mortality rate has increased by over $100 \%$ between 1970 and 2002. ${ }^{11-13}$ The economic costs for the management of this disease are staggering and these costs do not take into account the social burden of a reduced quality of life. ${ }^{14,15}$ While these figures are alarming, the true health burden of COPD is under-estimated, because airflow obstruction also significantly predisposes patients to other common causes of morbidity and mortality, including ischemic heart disease, stroke, pneumonia, and lung cancer. ${ }^{16,17}$

\section{Causes of COPD}

COPD is a progressive inflammatory condition of the lung caused predominantly by inhalation of noxious gasses and PM. ${ }^{4-7}$ Cigarette smoking (active or passive) is thought to be responsible for the vast majority of COPD; however, increasingly, other sources of exposure such as the burning of biomass fuels for heating and cooking, working in polluted indoor and outdoor environments, and exposure to ambient PM by exhaust from internal combustion engines, industrial emissions, and forest fires, are recognized as significant contributors to the development, progression, and exacerbation of COPD. ${ }^{18-23}$ Among all the lung diseases, COPD is the most highly correlated with air pollution exposure and has been linked to rapid global urbanization. ${ }^{18-22}$ The second major determinant of COPD is the host response to these inhaled stimuli where persons with $\alpha-1$ antitrypsin deficiency, ${ }^{24}$ a positive family history for COPD, ${ }^{25,26}$ a history of repeated respiratory tract infections in childhood, ${ }^{27}$ increased responsiveness to inhaled irritants, ${ }^{28}$ and female gender ${ }^{29,30}$ have been shown to be at greater risk for an equivalent exposure to chronic inhalation injury. The repetitive nature of this inhalation injury is central to all these exposures and pivotal to the chronic and progressive nature of COPD.

\section{Particulate matter exposure and COPD} Epidemiological evidence

The relationship between increased levels of air pollution and the mortality and morbidity rates from respiratory diseases is well-established..$^{31,32}$ Respiratory morbidity and mortality are also related to admissions for pneumonia, asthma, pulmonary emboli, and COPD. ${ }^{33}$ Of all the pollutants, inhalable particulate matter $\left(\mathrm{PM}_{10}\right)$ shows a strong association with adverse respiratory health effects, even when adjusted for other major risk factors such as cigarette smoking. ${ }^{31}$ Acute exacerbations of COPD, chronic bronchitis (CB), or emphysema have been associated with short-term exposure to air pollution. ${ }^{33}$ Older studies have shown that high levels of ambient particles were related to increased prevalence of chronic bronchitis ${ }^{34}$ and more recent studies predominantly relate respiratory symptoms to long-term effects of ambient particles. ${ }^{35,36}$ Recent cross-sectional studies showed an association between exposure to ambient $\mathrm{PM}_{10}$ in particular urban traffic related PM, a decline in forced expiratory volume in one second $\left(\mathrm{FEV}_{1}\right)$, and the development of COPD. ${ }^{19}$ In this study, Schikowski and colleagues ${ }^{19}$ showed in a cross-sectional study of women, using the Global Initiative for Chronic Obstructive Lung Disease (GOLD) criteria to define $\mathrm{COPD}$, that a $7 \mu \mathrm{g} / \mathrm{m}^{3}$ increase in ambient $\mathrm{PM}_{10}$ (over five years) was associated with a $5.1 \%$ more rapid decline in $\mathrm{FEV}_{1}$ (Figure 1) and an odds ratio (OR) of 1.33 for the development of COPD. Moreover, they showed living less than 100 meters from a busy artery road had a significant (OR 1.79) detrimental effect on lung function. ${ }^{19}$ These findings suggest that long-term exposure to ambient $\mathrm{PM}_{10}$ and living near a major road both increase the risk of developing COPD and accelerate loss of lung function. It is interesting to note that in COPD, the PM, as opposed to gases such as nitrogen dioxide and ozone, are the strongest associated with increased mortality. ${ }^{37}$

\section{Pathogenesis of PM-induced COPD}

\section{Clearance of PM from the lung}

The main mechanisms of deposition of PM in the lungs are impaction, sedimentation, and diffusion. ${ }^{38}$ Impaction is thought to be the principal mechanism of large PM deposition (greater than $100 \mu \mathrm{m}$ ). Larger particles usually travel on an initial path until they are deflected by a branching airway. Sedimentation happens to particles that are allowed to fall under their own force of gravity. This mechanism is largely considered to affect those particles between the aerodynamic diameter of $0.1 \mu \mathrm{m}$ and $50 \mu \mathrm{m}$. Finally, diffusion affects the smallest particles as they are displaced by random gas motion and will principally occur in the small airways and gas exchange regions of the lung. 


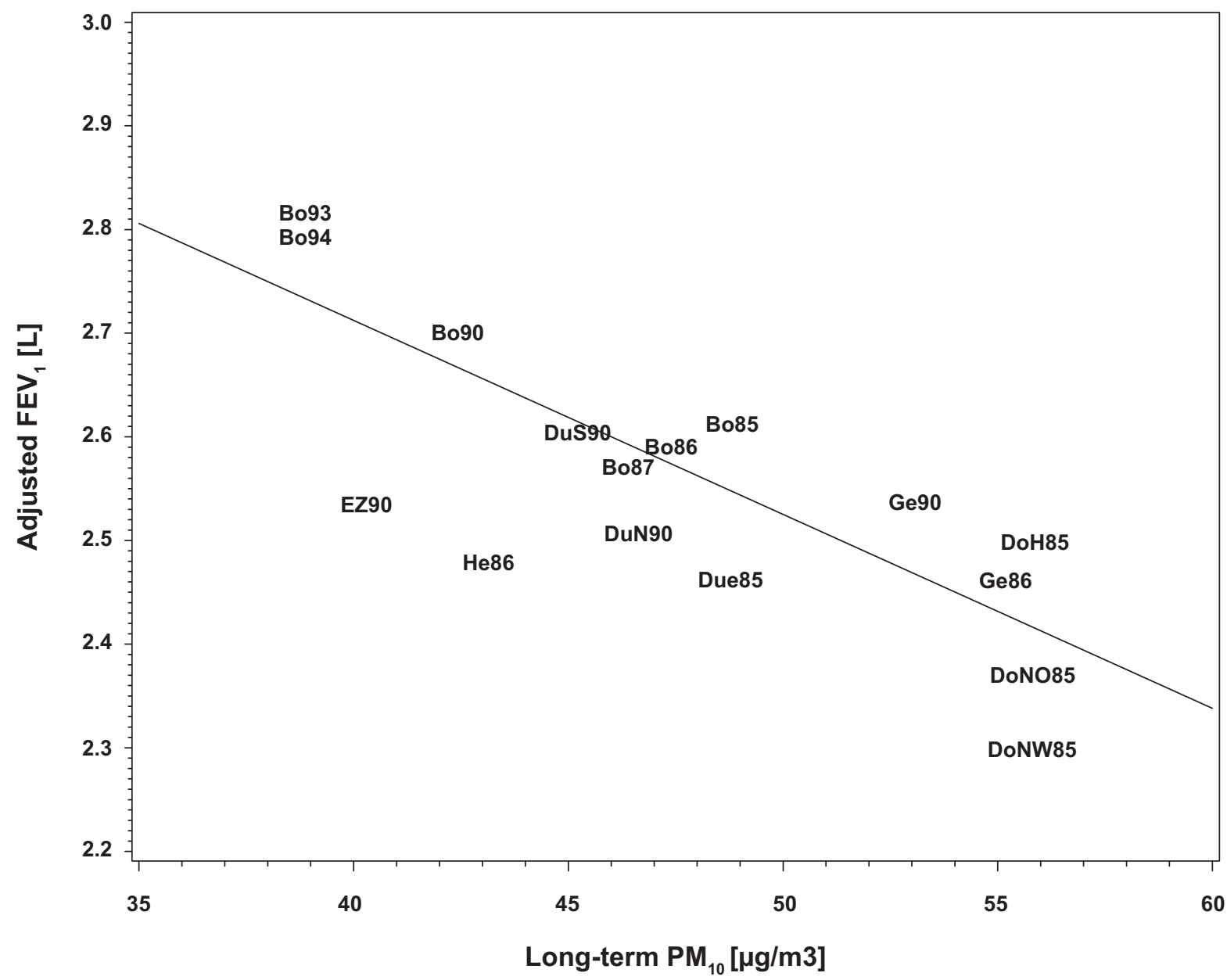

Figure I Association between FEV , and long-term $\mathrm{PM}_{10}$ exposure (five-year mean). Data points are means of each place and year of study. Abbreviations: $\mathrm{FEV}_{1}$, forced expiratory volume in one second; PM, particulate matter.

The respiratory tract is lined with thin liquid layer known as the epithelial lining fluid (ELF). This fluid both covers and protects the epithelial cells and is composed of various neutralizing agents such as antioxidants, lysozyme defensins, lipids, mucins, and proteins. ${ }^{39}$ The main component of the ELF is surfactant, whose well documented main function is to reduce surface tension, but another ability of surfactant is to displace PM less than $6 \mu \mathrm{m}$ in diameter to allow for easier mucociliary clearance..$^{40}$ Proteins in surfactant, in addition to the possibility of opsonization, help macrophages target and clear PM. ${ }^{39}$ It seems, that in addition to the neutralizing agents and proteins natively present in surfactant, the ELF can lead to the physical aggregation of ultrafine PM into agglomerates of greater than $5 \mu \mathrm{m}$ in diameter, which is more easily phagocytozed by macrophages. ${ }^{39}$ Some materials that land on the ELF are soluble, and these dissolve and may eventually transfer into the bloodstream. ${ }^{41}$ Another pathway for the soluble material to follow is the lymphatic channel, regional tracheobronchial lymph nodes, and eventually, to the blood circulation. ${ }^{38}$

Lung phagocytes are the first line of defense in the cellular response of the lungs to inhaled PM and microorganisms. ${ }^{42}$ The most important of these lung phagocytes in PM clearance is the alveolar macrophage (AM). AMs are located on the epithelial surfaces of either the alveoli or airways. ${ }^{43,44}$ Particles that cannot be cleared by the mucociliary action and coughing are processed by macrophages. ${ }^{41,43}$ Their primary role is to act as a barrier to inhaled matter by phagocytosing particles and intracellularly processed them. ${ }^{41,45}$ For the most part, there is a direct, positive relationship between the extent of PM and the number of AMs. ${ }^{46}$ Several recent studies have pointed to ultrafine particles as more dangerous than larger particles ${ }^{47,48}$ supporting Brain's ${ }^{46}$ observations in the 1960's that per weight, smaller particles elicit a stronger inflammatory response largely due to the greater number of particles and larger surface area to interact with biological surfaces. 
Alveolar macrophages can also go into an "overloaded" state, ${ }^{42}$ which inhibits their phagocytic and chemotactic activity when they have phagocytosed particles greater than $60 \%$ of their total internal volume. ${ }^{49,50}$ In a study by Morrow, ${ }^{50}$ it was found that if phagocytosed PM constituted only $6 \%$ of the total volume of AMs, the AMs ability to migrate to the mucocilliary escalator was compromised. Phagocytosis of certain particles such as silica, can damage or kill AM, releasing its contents that then fuels a perpetual inflammatory response. ${ }^{45}$ Furthermore, activation of AMs following PM phagocytosis, release copious amounts of oxygen radicals, proteases, pro-inflammatory mediators and growth-regulating proteins that can result in the pathogenesis of both acute and chronic lung inflammation. ${ }^{42,44}$

\section{Lung inflammation induced by PM}

Although much of the literature has focused on the size of the particles, numerous workers have explored the importance of the composition of PM..$^{51}$ There is a plethora of sources for PM that are both geogenic and anthropogenic. ${ }^{52}$ The injurious effects of this ambient particulate matter (from either cigarette smoking or air pollution) are both local (in the lung) and systemic. The AMs and bronchial and alveolar epithelial cells are the principle cells that process inhaled airborne particles in the lung. In processing these particles, they produce pro-inflammatory mediators that have the ability to elicit both a local inflammatory response in the lung tissues, but also a systemic inflammatory response..$^{53,54}$

\section{AM responses to $\mathrm{PM}$ exposure}

Exposure of AM to atmospheric particles influences their phagocytic activity, increases their oxidant production, and releases pro-inflammatory mediators such as tumor necrosis factor (TNF)- $\alpha$ and interleukin (IL)-1ß that are important in mediating the local and systemic inflammatory response. ${ }^{54}$ In addition to the acute response cytokines TNF $\alpha$ and IL-1 $\beta$, AMs produce a broad range of other cytokines, in particular IL-6, IL-8, macrophage inflammatory protein (MIP)-1 and granulocyte macrophage colony-stimulating factor (GM-CSF) when incubated ex vivo to ambient particles. ${ }^{55} \mathrm{IL}-8$ is critically important as chemoattractant and leukocyte activator and facilitates the recruitment of both polymorphonuclear leukocytes (PMNs) and monocytes into the airspaces. GM-CSF is not only a hematopoietic growth factor but has also an important granulocyte degranulation factor that enhances tissue damage induced by granulocytes. ${ }^{56} \mathrm{IL}-1 \beta$ is one of the "acute response" cytokines that induces cytokine production by many cells and has a broad stimulating effect on B- and T-cells. IL-10, a cytokine known to inhibit the production of pro-inflammatory cytokines such as TNF- $\alpha$, L-1 $\beta$, IL-6 and IL-8, however, is not stimulated by particle exposure, ${ }^{55}$ suggesting that $\mathrm{PM}$ does not induce a significant anti-inflammatory cytokine response. Collectively, these mediators released from AM when exposed to particles have the ability to elicit a pro-inflammatory response in the lung by stimulating other cells, such as, epithelial and endothelial cells that control and promote leukocyte recruitment into lung tissues and air spaces. In addition, exposure to ambient particles also compromise the response of AM to infectious agents possibly via an oxygen radical-mediated process by decreasing the AM's ability to phagocytose bacteria..$^{57-60}$ These studies suggested that the functional capacity of AM is modulated by exposure to PM in such a manner that it decreases the lung host defences. Therefore, PM exposure and retention in the lungs of COPD subject are critically important in promoting ongoing inflammation in the lung and could compromise local immune responses to infection resulting in more frequent COPD exacerbations.

\section{Lung epithelial cell response to PM}

Due to its large surface area, lung epithelial cells bear the brunt of exposure to inhaled particles and are critically important in processing these particles. Several studies, ${ }^{56,61-63}$ including studies from our own laboratory, ${ }^{61,62}$ have shown that lung epithelial cells exposed to PM produce several pro-inflammatory mediators such as GM-CSF, IL-1 $\beta$, IL-8, MCP-1, and leukemia inhibitory factor (LIF). These mediators are both important chemoattractants for leukocytes and up-regulate the expression of adhesion molecules, such as inter-cellular adhesion molecule-1 (ICAM-1), on their cell surface to promote leukocyte recruitment into the airspaces. Furthermore, studies have implicated persistence of the E1A gene of adenovirus in the amplification of cigarette smoke-induced lung inflammation in subjects with COPD. ${ }^{64-67}$ Lung epithelial cells transfected with the E1A gene of adenovirus amplified the production of pro-inflammatory mediators following exposure to ambient particles, ${ }^{6,67}$ suggesting additional pathways for how the retention of PM in the lung could contribute to persistence lung inflammation in COPD. Furthermore, studies from our laboratory have shown that exposure to ambient PM promote AM and lung epithelial interaction with synergetic production of pro-inflammatory mediators such as GM-CSF and IL- $6 .{ }^{61}$ In human studies, it has also been shown that controlled exposure of volunteers to PM can induce an inflammatory response in the airways with an increase in neutrophil trafficking and inflammatory cytokines and chemokines in the airways. ${ }^{68,69}$ These inflammatory mediators can damage the airways, resulting a higher susceptibility to bacterial, fungal, or viral infections. ${ }^{63}$ These infections, in turn, 
induce an adaptive immune response ${ }^{70}$ that can exacerbate the symptoms of asthma or COPD.

Collectively these studies suggest that AM and lung epithelial cells determine the profile and the magnitude of the mediator response in the lung following exposure to PM. Interestingly, these mediators are remarkably similar to mediators implicated in the pathogenesis, development, and progression of COPD, suggesting potential common inflammatory pathways stimulated when PM from different sources (cigarette smoke, ambient PM, wood smoke, etc.) are processed and retained in the lung.

\section{Particulate matter in lung tissues of COPD}

The major conduit for translocation of PM into the body is the respiratory tract. ${ }^{71}$ The majority of the biggest particles $(>5 \mu \mathrm{m})$ and the very smallest $(<0.001 \mu \mathrm{m})$ deposit in the nasal, pharyngeal, and laryngeal regions based on a predictive mathematical model from the International Commission on Radiological Protection in 1994..$^{48,71}$ It is actually the particle range between 0.1 and $0.001 \mu \mathrm{m}$ that is clinically relevant because it is this fraction that is deposited in the alveolar ducts and sacs. ${ }^{71}$ The dose of inhaled particles delivered to any region of the lung depends on the balance between their deposition and clearance. There appears to be a tendency for particles to concentrate in the centrilobular emphysematous lesions. ${ }^{72}$ This association between PM accumulation and emphysematous destruction suggests that the retained particulates either drive the inflammatory process that underlies the pathogenesis of COPD, that these particles accumulate in regions of lung inflammation and cause destruction, or it could be a combination of these two processes. In previous studies from our laboratories, where we determined the relationship between severity of COPD and lung inflammation ${ }^{4}$ and observed the presence of retained PM in different lung tissues, in particular smaller airways, alveolar macrophages, bronchial associated lymphoid tissues (BALT), and blood vessels (Figure 2). Churg and colleagues ${ }^{73}$ showed accumulation of carbonaceous aggregates of ultrafine particles present in the small airway mucosa in four nonsmokers in highly polluted Mexico City, suggesting that PM penetrates into and is retained in the walls of small airways even in nonsmokers. They speculate that long-term exposure to high levels of ambient particulate pollutants results in small airway remodeling that could produce chronic airflow obstruction similar to what is observed in COPD.

\section{Lung inflammation caused by PM in COPD}

COPD is characterized by chronic airways inflammation and remodeling, lung parenchymal inflammation, and destruction resulting in expiratory airflow obstruction, hyperinflation of the lung with loss of elastic recoil and, ultimately, disturbance of gas exchange. ${ }^{5}$ The inflammatory process is characterized by the recruitment of inflammatory immune cells in the terminal conducting airways. ${ }^{4,5}$ This inflammatory response is also associated with a repair and remodeling process that obstructs the small conducting airways resulting in expiratory airflow limitation that is poorly reversible with the use of bronchodilators. ${ }^{4,5,7,74,75}$ Increased numbers of neutrophils and macrophages are usually found in the small airways, with a mucosal increase in the numbers of inflammatory cells, including subepithelial CD68+ macrophages and CD8+ T-cells. ${ }^{4}$ Neutrophils are also increased in the bronchial walls and glands of patients with COPD further supporting a role of these cells in the pathogenesis of airflow limitation. ${ }^{4,74,75}$ In an ex vivo model of PM exposure, Churg and colleagues ${ }^{76}$ used ambient PM and showed activation of nuclear factor-kappaB (NF-KB) in epithelial cells in rat tracheal explants. In their in vivo model, they showed that the inflammatory response in the small airways is characterized by tissue proliferation with thickening of airway walls and obstruction of airflow. It is reasonable to postulate that these changes in the smaller airways could contribute to the retention of PM in airways (Figure 2) and eventual progression of airways inflammation and obstruction.

In the lung parenchyma, inflammation in COPD is characterized by accumulation of macrophages, neutrophils, and sometimes eosinophils in airspaces. ${ }^{4,5,7,74,75}$ This inflammatory reaction results in emphysematous destruction of alveolar walls thought to be induced by oxidative stress, apoptosis, and proteolysis of lung tissues. ${ }^{74,75,77,78}$ The nature of tissue inflammation favors tissue proliferation in the small airways and tissue destruction in the lung parenchyma. ${ }^{4,5}$ Clearly, distinct inflammatory pathways are activated in airway walls, in contrast to lung parenchyma that will influence the deposition and retention and possibly the inflammatory response elicited by PM in different regions of the lung.

Inflammatory mediators involved in COPD inflammation and those elicited by PM exposure of lung cells are remarkably similar. Increased levels of pro-inflammatory mediators such as IL-6, IL-1 $\beta$, TNF- $\alpha$, and IL- 8 have been observed in induced sputum from patients with stable COPD. ${ }^{79}$ These airway space mediators are produced predominantly by macrophages (IL-8, IL-1 $\beta$, TNF- $\alpha$, growth related oncogene- $\alpha$ [GRO- $\alpha]$, epithelial cell-derived neutrophil activating peptide [ENA-78], MCP-1, IL-10) and epithelial cells (IL-8, G-CSF, MCP-1) and are involved in neutrophil and monocyte recruitment into airspaces.$^{80}$ Elastase and matrix metalloproteinase (MMP) activation that are released from neutrophils and macrophages are considered to be a important 

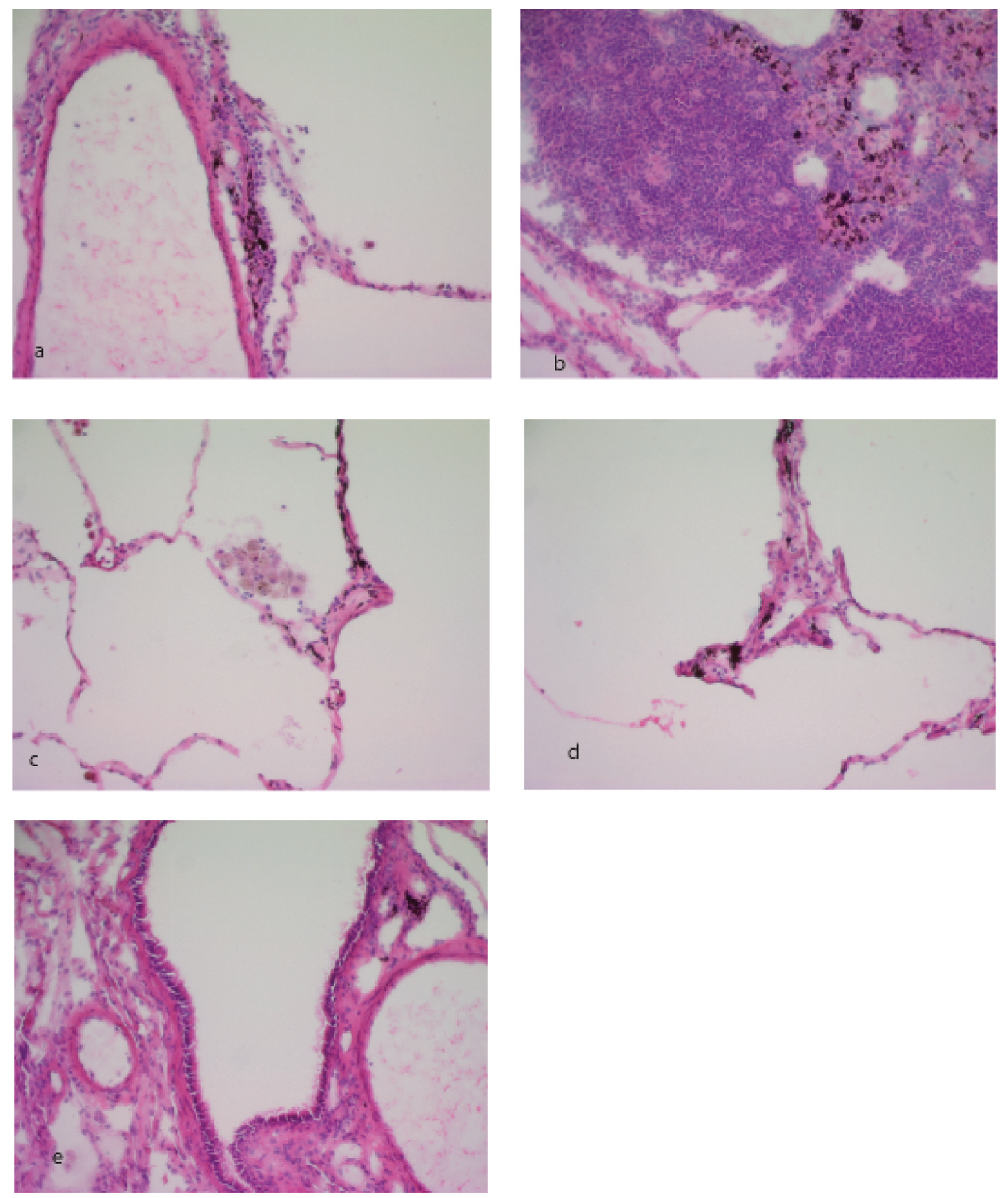

Figure 2 Particulate matter (PM) found in a) the blood vessel walls, b) lymphoid tissue, c) alveolar macrophages, d) Parenchyma, e) and airway wall, Sections from human lung tissuestained with H\&E.

mediators of lung parenchyma tissue damage in COPD, and recent studies showed that this process is driven by pro-inflammatory cytokines such as TNF- $\alpha$ which appears to be a key initiating mediator. ${ }^{81}$ Macrophage MMP activity and expression was upregulated in a study by Montano and colleagues, ${ }^{82}$ suggesting that this activity results in emphysematous destruction. Production of these mediators by PM deposited and retained in emphysematous regions of the lung will be able to activate the proteolytic pathway (eg, myeloperoxidase, elastase, MMP's) and also stimulate the production of molecules such as IL-8 and ENA-78 involved in neutrophil recruitment and activation. 
In a rat model, intratracheal instillation of $\mathrm{PM}_{10}$ resulted in a neutrophil influx in combination with an increase in endothelial permeability ${ }^{53}$ This study by Li and colleagues also showed that PM exposure precipitates free radical activity. PM has also been shown to be genotoxic to alveolar epithelial cells: causing both apoptosis and DNA damage through a mitochondria-related death and free radical pathway. ${ }^{83}$ This oxidative stress could be the result of structural damage inflicted onto the mitochondria by intracellular PM. ${ }^{84}$ In addition, PM also results in an induction of heme oxygenase-1 (HO-1), which is a key marker for oxidative stress. ${ }^{84}$ Oxidative stress appears to be a very important pathway for the deleterious effects of PM exposure. ${ }^{85}$

\section{Adverse health effects of PM in COPD \\ Exacerbations of COPD induced by $\mathrm{PM}$ exposure}

Exacerbations are considered to be one of the most important causes for morbidity and mortality linked with COPD. ${ }^{86}$ COPD exacerbations are most likely caused by viral or bacterial infections. However, there are good epidemiological data that implicate exposure to inhaled PM to either initiate or contribute with other factors such as infection, to precipitate exacerbations. ${ }^{3,86,87}$ Dominici and colleagues ${ }^{87}$ reported a near doubling in admissions for COPD exacerbations for every $10 \mu \mathrm{gm}^{3}$ of increase in $\mathrm{PM}_{2.5}$. Regardless of the different measures of PM exposure and health endpoints used in various studies; ultimately, they each support the association between PM exposure and increased COPD morbidity. ${ }^{3}$ In addition to morbidity, epidemiological evidence points to an increased mortality rate among COPD patients immediately following exposure to air pollution particles. ${ }^{3}$ Components of air pollution, such as, sulfur dioxide $\left(\mathrm{SO}_{2}\right)$, nitrogen dioxide $\left(\mathrm{NO}_{2}\right)$, and PM smaller than or equal to $10 \mathrm{um}$ in aerodynamic diameter $\left(\mathrm{PM}_{10}\right)$, have been all been implicated to increase respiratory mortality in COPD patients. ${ }^{88}$ For this reason, governments worldwide have introduced air quality guidelines. The goal of these guidelines are to decrease levels of deleterious PM; ${ }^{89}$ however, levels are frequently exceeded. For example, in a study from the United Kingdom, levels exceeding guidelines have been implicated in 8,000 deaths and 10,000 excess hospital admissions annually from airway disease exacerbation. ${ }^{89}$

\section{Development and progression of COPD induced by PM exposure}

There is strong epidemiological evidence that exposure to ambient air pollutants causes exacerbations of pre-existing COPD, but very little evidence that it actually causes the development or progression of COPD. Schikowski and colleagues ${ }^{19}$ followed women living near high traffic areas or industrial sources

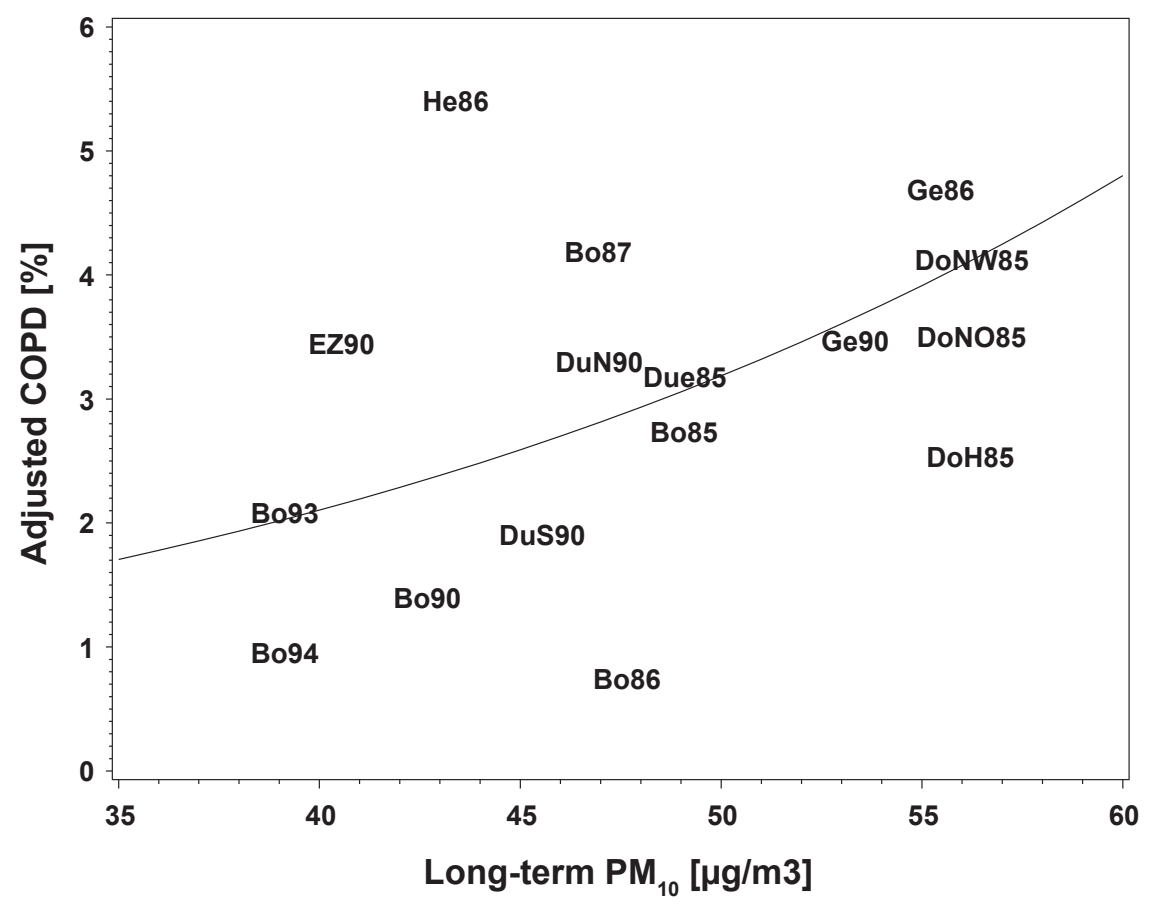

Figure 3 Association between COPD and long-term PM ${ }_{10}$ exposure (five-year mean). Data points are means of each place and year of study. Abbreviations: COPD, chronic obstructive pulmonary disease; PM, particulate matter. 
Table I Key studies in the role of particulate matter in the development and progression of COPD

\begin{tabular}{|c|c|}
\hline \multicolumn{2}{|c|}{ Epidemiological evidence } \\
\hline Author(s) & Study description \\
\hline Schikowski et al ${ }^{19}$ & $\begin{array}{l}\text { Long term exposure to air pollution from high traffic and industrial sources resulted in } \\
\text { rapid decline of } \mathrm{FEV}_{1} \text {, a high risk ratio to develop COPD, and poorer respiratory health }\end{array}$ \\
\hline Liu et $\mathrm{al}^{18}$ & $\begin{array}{l}\text { Significant association between prevalence of COPD and biomass fuel for cooking in } \\
\text { rural China }\end{array}$ \\
\hline Viegi et $\mathrm{al}^{21}$ & $\begin{array}{l}\text { Exposure to PM by internal combustion and industrial emissions recognized as significant } \\
\text { contributors to exacerbation of COPD }\end{array}$ \\
\hline Dockery et al ${ }^{32}$ & $\begin{array}{l}\text { Relationship between increased levels of air pollution and mortality and morbidity rates } \\
\text { from respiratory diseases }\end{array}$ \\
\hline Torres-Duque et $\mathrm{a}^{23}$ & Indoor air pollution from the combustion of biomass fuels related to respiratory diseases \\
\hline Sunyer et al ${ }^{\prime}$ & $\begin{array}{l}\text { Effect of acute increase in urban air pollution on respiratory health and what factors } \\
\text { could attribute to this effects }\end{array}$ \\
\hline Sint et $\mathrm{al}^{3}$ & $\begin{array}{l}\text { COPD patients have an increased sensitivity to PM and should reduce their exposure to } \\
\text { PM whenever possible }\end{array}$ \\
\hline \multicolumn{2}{|c|}{ Alveolar macrophage (AM) response to $\mathrm{PM}$} \\
\hline van Eeden et $\mathrm{a}^{54}$ & $\begin{array}{l}\text { Exposure of lung macrophages to atmospheric particles influences their phagocytic } \\
\text { activity and pro-inflammatory responses }\end{array}$ \\
\hline Oberdorster et $\mathrm{al}^{71}$ & $\begin{array}{l}\text { Suggests a duel role of lung macrophages exposed to PM: both preventing and contribut- } \\
\text { ing to chronic lung injury }\end{array}$ \\
\hline Morrow $^{50}$ & $\begin{array}{l}\text { Reviews possible mechanisms as to how dust overloading can compromise the phago- } \\
\text { cytic and chemotactic ability of AMs }\end{array}$ \\
\hline \multicolumn{2}{|c|}{ Lung inflammation in response to PM } \\
\hline Churg et $\mathrm{al}^{76}$ & Particulate matter activates NF-KB in tracheal epithelial cells \\
\hline Montano et a ${ }^{82}$ & $\begin{array}{l}\text { Increase MMP activity in macrophages exposed to wood smoke, suggesting subsequent } \\
\text { emphysematous destruction }\end{array}$ \\
\hline Risom et $a^{85}$ & $\begin{array}{l}\text { Particulate matter induced oxidative stress-induced DNA damage is an important ways in } \\
\text { which PM can be harmful }\end{array}$ \\
\hline Li et $\mathrm{al}^{53}$ & $\begin{array}{l}\text { PM induces } \mathrm{HO}-\mathrm{I} \text {, key marker for oxidative stress resulting in structural damage of } \\
\text { mitochondria }\end{array}$ \\
\hline
\end{tabular}

Abbreviations: COPD, chronic obstructive pulmonary disease; $\mathrm{FEV}_{1}$, forced expiratory volume in one second; PM, particulate matter.

longitudinally, and showed that long term exposure to air pollution from these sources resulted in more rapid decline in pulmonary function $\left(\mathrm{FEV}_{1}\right)$, a high risk ratio to develop COPD, and have poorer respiratory health (Figures 1 and 3). This study was the first to assess the impact of long-term air pollution on the development of COPD. In a cross-sectional study, Liu and colleagues ${ }^{18}$ showed a significant association between the prevalence of COPD and exposure to biomass fuel for cooking in rural China (corrected for multiple factors including smoking). This finding is supported by study from Kiraz and colleagues $^{90}$ showing that rural Chinese women exposed to biomass fumes are more likely to suffer from chronic bronchitis and COPD than urban women even though the prevalence of smoking is higher among the latter group. The World Health Organization (WHO) has estimated that more than 1.6 million deaths and over 38.5 million disability-adjusted life-years can be attributable to indoor smoke from the use of biomass fuels, affecting mainly children and women. ${ }^{23}$ Together these studies suggest that exposures other that tobacco smoke could also lead to the development of COPD. Interestingly, a wide range of studies suggest that only $15 \%$ to $25 \%$ of smokers actually develop clinical COPD, but virtually $100 \%$ of smokers have airway inflammation that may include observable respiratory bronchiolitis. ${ }^{89,91}$ These observations underline the importance of the interaction of genetic factors and susceptibility with environmental exposures to produce clinical COPD. Sezer and colleagues $^{92}$ found in a case control study that women afflicted with COPD, that exposure to both cigarette and biomass smoke for 30 or more years, were significant risk factors in the development of COPD. Earlier studies by Fletcher and Peto ${ }^{93}$ have shown that loss in lung function in smokers that develop COPD is a progressive process even after smoking cessation. This concept was supported by Hogg and colleagues: ${ }^{78}$ they showed an intense inflammatory response in the lungs of patients with end 
stage COPD who have stopped smoking for prolonged period of time. It is reasonable to postulate that risk factors independent of cigarette smoking such as occupational and environmental exposures cause progression of the disease process.

\section{Conclusions}

COPD is a chronic inflammatory condition of the airways and lung parenchyma and the importance of exposure and retention of particulate matter in the lung tissues on the pathogenesis of lung inflammation in COPD is still unclear. Numerous epidemiological studies have implicated exposure to a variety of ambient particles and gases to exacerbate symptoms of COPD, resulting in an increase in morbidity and mortality (Table 1). The predominant source of PM in the lungs of COPD patients is either PM inhaled from cigarette smoke or ambient air pollution particles from other sources: both have been associated with the development and progression of COPD. With the rapid urbanization of the population, a better understanding of the importance of the different sources of ambient PM on the development and progression of COPD is imperative for educational and preventative measures. Furthermore, determining the importance of retained PM in perpetual lung inflammation in COPD could lead to novel therapeutic interventions in the future.

\section{Disclosure}

This work was supported by the BC Lung Association and Heart and Stroke Foundation of Canada. Dr Stephan F van Eeden is the recipient of a Career Investigators Award from the American Lung Association, the William Thurlbeck Distinguished Researcher Award and a Senior Scholar of the Michael Smith Foundation for Health Research. The authors report no conflicts of interest in this work.

\section{References}

1. Sunyer J, Schwartz J, Tobias A, Macfarlane D, Garcia J, Anto JM. Patients with chronic obstructive pulmonary disease are at increased risk of death associated with urban particle air pollution: a case-crossover analysis. Am J Epidemiol. 2000;151(1):50-56.

2. Pabst M, Hofer F. Deposits of different origin in the lungs of the 5,300year-old Tyrolean Iceman. Am J Phys Anthropol. 1998;107(1):1-12.

3. Sint T, Donohue JF, Ghio AJ. Ambient air pollution particles and the acute exacerbation of chronic obstructive pulmonary disease. Inhal Toxicol. 2008;20(1):25-29.

4. Hogg JC, Chu F, Utokaparch S, et al. The nature of small-airway obstruction in chronic obstructive pulmonary disease. $N$ Engl J Med. 2004;350(26):2645-2653.

5. Hogg JC. Pathophysiology of airflow limitation in chronic obstructive pulmonary disease. Lancet. 2004;364(9435):709-721.

6. Murray CJ, Lopez AD. Global mortality, disability, and the contribution of risk factors: Global Burden of Disease Study. Lancet. 1997;349(9063):1436-1442.

7. Mannino DM, Watt G, Hole D, et al. The natural history of chronic obstructive pulmonary disease. Eur Respir J. 2006;27(3):627-643.
8. Calverley PM, Walker P. Chronic obstructive pulmonary disease. Lancet. 2003;362(9389):1053-1061.

9. Pauwels R. Global initiative for chronic obstructive lung diseases (GOLD): time to act. Eur Respir J. 2001;18(6):901-902.

10. Buist AS, McBurnie MA, Vollmer WM, et al. International variation in the prevalence of COPD (the BOLD Study): a population-based prevalence study. Lancet. 2007;370(9589):741-750.

11. Chapman KR, Bourbeau J, Rance L. The burden of COPD in Canada: results from the Confronting COPD survey. Respir Med. 2003; 97(Suppl C):S23-S31.

12. Miolla M. The cost of chronic disease in Canada. 1994. Accecssed June 3, 2009. Available from: http://www.gpiatlantic.org/pdf/health/ chroniccanada.pdf.

13. Rabe KF, Hurd S, Anzueto A, et al. Global strategy for the diagnosis, management, and prevention of chronic obstructive pulmonary disease: GOLD executive summary. Am J Respir Crit Care Med. 2007;176(6):532-555.

14. Ferrer M, Alonso J, Morera J, et al. Chronic obstructive pulmonary disease stage and health-related quality of life. The Quality of Life of Chronic Obstructive Pulmonary Disease Study Group. Ann Intern Med. 1997;127(12):1072-1079.

15. Sullivan SD, Ramsey SD, Lee TA. The economic burden of COPD Chest. 2000;117(2 Suppl):5S-9S.

16. Sin DD, Anthonisen NR, Soriano JB, Agusti AG. Mortality in COPD: Role of comorbidities. Eur Respir J. 2006;28(6):1245-1257.

17. Sin DD, Wu L, Man SF. The relationship between reduced lung function and cardiovascular mortality: a population-based study and a systematic review of the literature. Chest. 2005;127(6):1952-1959.

18. Liu S, Zhou Y, Wang X, et al. Biomass fuels are the probable risk factor for chronic obstructive pulmonary disease in rural South China. Thorax. 2007;62(10):889-897.

19. Schikowski T, Sugiri D, Ranft U, et al. Long-term air pollution exposure and living close to busy roads are associated with COPD in women. Respir Res. 2005;6:152.

20. Lipton R, Banerjee A, Dowling KC, Treno AJ. The geography of COPD hospitalization in California. COPD. 2005;2(4):435-444.

21. Viegi G, Maio S, Pistelli F, Baldacci S, Carrozzi L. Epidemiology of chronic obstructive pulmonary disease: health effects of air pollution. Respirology. 2006;11(5):523-532.

22. Ekici A, Ekici M, Kurtipek E, et al. Obstructive airway diseases in women exposed to biomass smoke. Environ Res. 2005;99(1):93-98.

23. Torres-Duque C, Maldonado D, Perez-Padilla R, Ezzati M, Viegi G. Biomass fuels and respiratory diseases: a review of the evidence. Proc Am Thorac Soc. 2008;5(5):577-590.

24. Hersh CP, Dahl M, Ly NP, Berkey CS, Nordestgaard BG, Silverman EK Chronic obstructive pulmonary disease in alpha1-antitrypsin PI MZ heterozygotes: a meta-analysis. Thorax. 2004;59(10):843-849.

25. Silverman EK, Chapman HA, Drazen JM, et al. Genetic epidemiology of severe, early-onset chronic obstructive pulmonary disease. Risk to relatives for airflow obstruction and chronic bronchitis. Am J Respir Crit Care Med. 1998;157(6 Pt 1):1770-1778.

26. Cohen BH, Ball WC Jr, Bias WB, et al. A genetic-epidemiologic study of chronic obstructive pulmonary disease. I. Study design and preliminary observations. Johns Hopkins Med J. 1975;137(3):95-104.

27. Hogg JC. Childhood viral infection and the pathogenesis of asthma and chronic obstructive lung disease. Am J Respir Crit Care Med. 1999;160(5 Pt 2):S26-S28.

28. Tashkin DP, Altose MD, Connett JE, Kanner RE, Lee WW, Wise RA. Methacholine reactivity predicts changes in lung function over time in smokers with early chronic obstructive pulmonary disease. The Lung Health Study Research Group. Am J Respir Crit Care Med. 1996;153(6 Pt 1):1802-1811.

29. Anthonisen NR, Connett JE, Murray RP. Smoking and lung function of Lung Health Study participants after 11 years. Am J Respir Crit Care Med. 2002;166(5):675-679.

30. Manfreda J, Sears MR, Becklake MR, et al. Geographic and gender variability in the prevalence of bronchial responsiveness in Canada. Chest. 2004;125(5):1657-1664. 
31. Schwartz J. Short term fluctuations in air pollution and hospital admissions of the elderly for respiratory disease. Thorax. 1995;50(5):531-538.

32. Dockery DW, Pope CA, 3rd, Xu X, et al. An association between air pollution and mortality in six US cities. N Engl J Med. 1993;329(24):1753-1759.

33. Atkinson RW, Anderson HR, Sunyer J, et al. Acute effects of particulate air pollution on respiratory admissions: results from APHEA 2 project. Air Pollution and Health: a European Approach. Am J Respir Crit Care Med. 2001;164(10 Pt 1):1860-1866.

34. Bouhuys A, Beck GJ, Schoenberg JB. Do present levels of air pollution outdoors affect respiratory health? Nature. 1978;276(5687):466-471.

35. Karakatsani A, Andreadaki S, Katsouyanni K, et al. Air pollution in relation to manifestations of chronic pulmonary disease: a nested casecontrol study in Athens, Greece. Eur J Epidemiol. 2003;18(1):45-53.

36. Chestnut LG, Schwartz J, Savitz DA, Burchfiel CM. Pulmonary function and ambient particulate matter: epidemiological evidence from NHANES I. Arch Environ Health. 1991;46(3):135-144.

37. Sunyer J, Basagana X. Particles, and not gases, are associated with the risk of death in patients with chronic obstructive pulmonary disease. Int J Epidemiol. 2001;30(5):1138-1140.

38. Stuart BO. Deposition and clearance of inhaled particles. Environ Health Perspect. 1976;16:41-53.

39. Kendall M, Tetley TD, Wigzell E, Hutton B, Nieuwenhuijsen M, Luckham P. Lung lining liquid modifies PM(2.5) in favor of particle aggregation: a protective mechanism. Am J Physiol Lung Cell Mol Physiol. 2002;282(1):L109-L114.

40. Schurch S, Gehr P, Im Hof V, Geiser M, Green F. Surfactant displaces particles toward the epithelium in airways and alveoli. Respir Physiol. 1990;80(1):17-32.

41. Kreyling WG. Intracellular particle dissolution in alveolar macrophages. Environ Health Perspect. 1992;97:121-126.

42. Oberdorster G, Ferin J, Gelein R, Soderholm SC, Finkelstein J. Role of the alveolar macrophage in lung injury: studies with ultrafine particles. Environ Health Perspect. 1992;97:193-199.

43. Geiser M. Morphological aspects of particle uptake by lung phagocytes. Microsc Res Tech. 2002;57(6):512-522.

44. Zhou H, Kobzik L. Effect of concentrated ambient particles on macrophage phagocytosis and killing of Streptococcus pneumoniae. Am J Respir Cell Mol Biol. 2007;36(4):460-465.

45. Bowden DH. The alveolar macrophage. Environ Health Perspect. 1984;55:327-341.

46. Brain JD. Mechanisms, measurement, and significance of lung macrophage function. Environ Health Perspect. 1992;97:5-10.

47. Gilmour PS, Ziesenis A, Morrison ER, et al. Pulmonary and systemic effects of short-term inhalation exposure to ultrafine carbon black particles. Toxicol Appl Pharmacol. 2004;195(1):35-44.

48. Johnson RL Jr. Relative effects of air pollution on lungs and heart. Circulation. 2004;109(1):5-7.

49. MacNee W, Donaldson K. Mechanism of lung injury caused by PM10 and ultrafine particles with special reference to COPD. Eur Respir $J$ Suppl. 2003;40:47s-51s.

50. Morrow PE. Possible mechanisms to explain dust overloading of the lungs. Fundam Appl Toxicol. 1988;10(3):369-384.

51. Alfaro-Moreno E, Nawrot TS, Nemmar A, Nemery B. Particulate matter in the environment: pulmonary and cardiovascular effects. Curr Opin Pulm Med. 2007;13(2):98-106.

52. Englert N. Fine particles and human health - a review of epidemiological studies. Toxicol Lett. 2004;149(1-3):235-242.

53. Li XY, Gilmour PS, Donaldson K, MacNee W. Free radical activity and pro-inflammatory effects of particulate air pollution (PM10) in vivo and in vitro. Thorax. 1996;51(12):1216-1222.

54. van Eeden SF, Yeung A, Quinlam K, Hogg JC. Systemic response to ambient particulate matter: relevance to chronic obstructive pulmonary disease. Proc Am Thorac Soc. 2005;2(1):61-67.

55. van Eeden SF, Tan WC, Suwa T, et al. Cytokines involved in the systemic inflammatory response induced by exposure to particulate matter air pollutants (PM(10)). Am J Respir Crit Care Med. 2001;164(5): $826-830$.
56. Carter JD, Ghio AJ, Samet JM, Devlin RB. Cytokine production by human airway epithelial cells after exposure to an air pollution particle is metal-dependent. Toxicol Appl Pharmacol. 1997;146(2):180-188.

57. Mundandhara SD, Becker S, Madden MC. Effects of diesel exhaust particles on human alveolar macrophage ability to secrete inflammatory mediators in response to lipopolysaccharide. Toxicol In Vitro. 2006;20(5):614-624.

58. Amakawa K, Terashima T, Matsuzaki T, Matsumaru A, Sagai M, Yamaguchi K. Suppressive effects of diesel exhaust particles on cytokine release from human and murine alveolar macrophages. Exp Lung Res. 2003;29(3):149-164.

59. Yang HM, Barger MW, Castranova V, Ma JK, Yang JJ, Ma JY. Effects of diesel exhaust particles (DEP), carbon black, and silica on macrophage responses to lipopolysaccharide: evidence of DEP suppression of macrophage activity. $J$ Toxicol Environ Health A. 1999;58(5):261-278.

60. Becker S, Soukup JM. Decreased CD11b expression, phagocytosis, and oxidative burst in urban particulate pollution-exposed human monocytes and alveolar macrophages. $J$ Toxicol Environ Health A. 1998;55(7):455-477.

61. Fujii T, Hayashi S, Hogg JC, et al. Interaction of alveolar macrophages and airway epithelial cells following exposure to particulate matter produces mediators that stimulate the bone marrow. Am J Respir Cell Mol Biol. 2002;27(1):34-41.

62. Fujii T, Hayashi S, Hogg JC, Vincent R, Van Eeden SF. Particulate matter induces cytokine expression in human bronchial epithelial cells. Am J Respir Cell Mol Biol. 2001;25(3):265-271.

63. Gilmour PS, Rahman I, Hayashi S, Hogg JC, Donaldson K, MacNee W. Adenoviral E1A primes alveolar epithelial cells to PM(10)-induced transcription of interleukin-8. Am J Physiol Lung Cell Mol Physiol. 2001;281(3):L598-L606.

64. Matsuse T, Hayashi S, Kuwano K, Keunecke H, Jefferies WA, Hogg JC. Latent adenoviral infection in the pathogenesis of chronic airways obstruction. Am Rev Respir Dis. 1992;146(1):177-184.

65. Meshi B, Vitalis TZ, Ionescu D, et al. Emphysematous lung destruction by cigarette smoke. The effects of latent adenoviral infection on the lung inflammatory response. Am J Respir Cell Mol Biol. 2002;26(1):52-57.

66. Keicho N, Elliott WM, Hogg JC, Hayashi S. Adenovirus E1A upregulates interleukin-8 expression induced by endotoxin in pulmonary epithelial cells. Am J Physiol. 1997;272(6 Pt 1):L1046-L1052.

67. Fujii T, Hogg JC, Keicho N, Vincent R, Van Eeden SF, Hayashi S. Adenoviral E1A modulates inflammatory mediator expression by lung epithelial cells exposed to PM10. Am J Physiol Lung Cell Mol Physiol. 2003;284(2):L290-L297.

68. Ghio AJ, Kim C, Devlin RB. Concentrated ambient air particles induce mild pulmonary inflammation in healthy human volunteers. Am J Respir Crit Care Med. 2000;162(3 Pt 1):981-988.

69. Salvi SS, Nordenhall C, Blomberg A, et al. Acute exposure to diesel exhaust increases IL-8 and GRO-alpha production in healthy human airways. Am J Respir Crit Care Med. 2000;161(2 Pt 1):550-557.

70. de Haar C, Hassing I, Bol M, Bleumink R, Pieters R. Ultrafine but not fine particulate matter causes airway inflammation and allergic airway sensitization to co-administered antigen in mice. Clin Exp Allergy. 2006;36(11):1469-1479.

71. Oberdorster G, Oberdorster E, Oberdorster J. Nanotoxicology: an emerging discipline evolving from studies of ultrafine particles. Environ Health Perspect. 2005;113(7):823-839.

72. Lippmann M, Yeates DB, Albert RE. Deposition, retention, and clearance of inhaled particles. Br J Ind Med. 1980;37(4):337-362.

73. Churg A, Brauer M, del Carmen Avila-Casado M, Fortoul TI, Wright JL. Chronic exposure to high levels of particulate air pollution and small airway remodeling. Environ Health Perspect. 2003;111(5):714-718.

74. Hogg JC, Senior RM. Chronic obstructive pulmonary disease part 2: pathology and biochemistry of emphysema. Thorax. 2002;57(9): 830-834.

75. Jeffery PK. Structural and inflammatory changes in COPD: a comparison with asthma. Thorax. 1998;53(2):129-136. 
76. Churg A, Xie C, Wang X, Vincent R, Wang RD. Air pollution particles activate NF-kappaB on contact with airway epithelial cell surfaces. Toxicol Appl Pharmacol. 2005;208(1):37-45.

77. Lim S, Roche N, Oliver BG, Mattos W, Barnes PJ, Chung KF. Balance of matrix metalloprotease-9 and tissue inhibitor of metalloprotease-1 from alveolar macrophages in cigarette smokers. Regulation by interleukin-10. Am J Respir Crit Care Med. 2000;162(4 Pt 1):1355-1360.

78. Hogg JC. Why does airway inflammation persist after the smoking stops? Thorax. 2006;61(2):96-97.

79. Keatings VM, Collins PD, Scott DM, Barnes PJ. Differences in interleukin-8 and tumor necrosis factor-alpha in induced sputum from patients with chronic obstructive pulmonary disease or asthma. Am J Respir Crit Care Med. 1996;153(2):530-534.

80. Masubuchi T, Koyama S, Sato E, et al. Smoke extract stimulates lung epithelial cells to release neutrophil and monocyte chemotactic activity. Am J Pathol. 1998;153(6):1903-1912.

81. Churg A, Wang RD, Tai H, Wang X, Xie C, Wright JL. Tumor necrosis factor-alpha drives $70 \%$ of cigarette smoke-induced emphysema in the mouse. Am J Respir Crit Care Med. 2004;170(5):492-498.

82. Montano M, Beccerril C, Ruiz V, Ramos C, Sansores RH, GonzalezAvila G. Matrix metalloproteinases activity in COPD associated with wood smoke. Chest. 2004;125(2):466-472.

83. Upadhyay D, Panduri V, Ghio A, Kamp DW. Particulate matter induces alveolar epithelial cell DNA damage and apoptosis: role of free radicals and the mitochondria. Am J Respir Cell Mol Biol. 2003;29(2):180-187.
84. Li N, Sioutas C, Cho A, et al. Ultrafine particulate pollutants induce oxidative stress and mitochondrial damage. Environ Health Perspect. 2003;111(4):455-460.

85. Risom L, Moller P, Loft S. Oxidative stress-induced DNA damage by particulate air pollution. Mutat Res. 2005;592(1-2):119-137.

86. Wedzicha JA, Donaldson GC. Exacerbations of chronic obstructive pulmonary disease. Respir Care. 2003;48(12):1204-1213; discussion 1213-1205.

87. Dominici F, Peng RD, Bell ML, et al. Fine particulate air pollution and hospital admission for cardiovascular and respiratory diseases. JAMA. 2006;295(10):1127-1134.

88. Papi A, Luppi F, Franco F, Fabbri LM. Pathophysiology of exacerbations of chronic obstructive pulmonary disease. Proc Am Thorac Soc. 2006;3(3):245-251.

89. MacNee W, Donaldson K. Exacerbations of COPD: environmental mechanisms. Chest. 2000;117(5 Suppl 2):390S-397S.

90. Kiraz K, Kart L, Demir R, et al. Chronic pulmonary disease in rural women exposed to biomass fumes. Clin Invest Med. $2003 ; 26(5): 243-248$.

91. Girod CE, King TE Jr. COPD: a dust-induced disease? Chest. 2005;128(4):3055-3064.

92. Sezer H, Akkurt I, Guler N, Marakoglu K, Berk S. A case-control study on the effect of exposure to different substances on the development of COPD. Ann Epidemiol. 2006;16(1):59-62.

93. Fletcher C, Peto R. The natural history of chronic airflow obstruction Br Med J. 1977;1(6077):1645-1648.
International Journal of COPD

\section{Publish your work in this journal}

The International Journal of COPD is an international, peer-reviewed journal of therapeutics and pharmacology focusing on concise rapid reporting of clinical studies and reviews in COPD. Special focus is given to the pathophysiological processes underlying the disease, intervention programs, patient focused education, and self management protocols.

\section{Dovepress}

This journal is indexed on PubMed Central, MedLine and CAS. The manuscript management system is completely online and includes a very quick and fair peer-review system, which is all easy to use. Visit http://www.dovepress.com/testimonials.php to read real quotes from published authors. 